\title{
Nietzsche, Decadence, and Regeneration in France, 1891-95
}

\author{
Christopher E. Forth
}

[I]t is impossible that I should allow myself to be constrained from greeting the few persons willing to

listen to me, by barriers which an abominable dynastic policy has erected between the peoples. And I gladly acknowledge that above all I seek such persons in France.

-FriedrichNietzsche, Letter to August Strindberg, Winter 1888

Among the numerous topics covered in the 1912 survey, Les jeunes gens d'aujourd' $h u i$, certain statements regarding the role of the philosopher Friedrich Nietzsche in French intellectual life merit attention. Conducted by the French nationalists Henri Massis and Alfred de Tarde (writing under the pseudonym "Agathon"), this enquête alleged that the intellectual generation of 1912 was at profound odds with the previous generation of 1890: whereas their elders escaped from reality into subjective aesthetics, renounced hope in political and social action, and strongly rejected nationalism, according to Agathon, the youth of 1912 stressed physical vitality and action, optimistically searched for political order, and ardently espoused nationalism, even to the point of accepting the inevitability of war with Germany. ${ }^{1}$

While the youth of 1912 were pleased with the "heroic optimism of Zarathustra, who counsels a dangerous ideal," Agathon asserted that Nietzsche

An abridged version of this essay was presented before the New York State Association of European Historians, Albany, N.Y., 20-21 September 1991. The author gratefully acknowledges Bernice Glatzer Rosenthal and Georg G. Iggers for their helpful comments, suggestions, and encouragement.

'Agathon [Henri Massis and Alfred de Tarde] Les jeunes gens d'aujourd 'hui (Paris, [1912] 1914), iii, 6, 9-10, 19; Robert Wohl, The Generation of 1914 (Cambridge, 1979), 8-9. 
was "read with difficulty by our youth" and added: "For the anaemic intelligences of our elders, he was a powerful cordial and prepared the restoration of courageous values, of force, of energy, [and] of the beautiful audacity of noble races." In the present, however, Agathon concluded that "the young people have no need for this 'tonic.'... This unhealthy taste for life, this anxious call for health inspires their mistrust. This obsession for what is vigorous and powerful, [and] the frantic apology for force seems justly suspect to a strong man. All that was in Nietzsche only a hygiene for neurasthenics has no more meaning for those who are coming."2 In short, the impotent generation of 1890 found a source of strength in the philosophy of Nietzsche; the youth of 1912, however, had found inspiration in the novelist Stendhal, the "Nietzsche of our race," who is "much closer to their soul."3 Thus Nietzsche was portrayed by Agathon as a stimulant for a weaker and more decadent era, a foreign influence which had no place among the stronger and militantly nationalist generation of $1912 .^{4}$

Agathon's remarks about the reception and appropriation of Nietzsche in France are provocative but nonetheless simplistic. In an effort to distinguish themselves from their elders - in fact, to define themselves in diametricallyopposed terms - the authors erroneously indicated a gap between the generations of 1890 and 1912, disregarding the intellectual transformation during the 1890 s which produced the world view of 1912 . Between the two generations there was a gradual intellectual transformation from decadence and individualism to vitalism and collective regeneration, a shift hastened by political scandals, socialist and anarchist agitation, the Dreyfus Affair, and the rise of French nationalism. ${ }^{5}$ The reception of Nietzsche by the French during this period of crisis was a symptom of and a catalyst for such a transformation. It was a "rhetoric of regeneration" which the ideas of Nietzsche most clearly contributed to French intellectual life at the turn of the century and which helps bridge the supposed gap that Agathon indicated between the generations of 1890 and 1912. The philosophy of Nietzsche inspired and legitimated a vitalistic desire for a radical change in the status quo, a program which would be appropriated by extremist groups on the left and the right.

The rhetoric of regeneration provided in part by Nietzsche's thought was initially expressed among French writers in two concurrent ways: negatively, by undermining the dominant literary school of decadent Symbolism through an

${ }^{2}$ Agathon, 55.

${ }^{3}$ Ibid.

${ }^{4}$ Henri Massis explained his relationship with Nietzsche's thought in a survey conducted in 1930 by a German scholar, Jean R. Kückenburg. Massis wrote: "As a student I read Nietzsche with enthusiasm, but during the crises which I went through, like all other young men, his teaching helped me not at all, in fact, rather hindered me, in finding a passable road to society." Cf. Anonymous, "French Views on Nietzsche," Living Age, 339 (November 1930), 315. 84.

${ }^{5}$ Eugen Weber, The Nationalist Revival in France, 1905-1914 (Berkeley, 1959), 35-42, 77 - 
attack on one of its main pillars, the composer Richard Wagner, and positively, by being simultaneously appropriated to legitimate the regenerative programs of literary anarchism, socialism, and certain conservative political positions. That these two phenomena occurred simultaneously suggests the radical effect that Nietzsche had on many French intellectuals and hints at the transformation of the literary field which took place during the 1890s. Agathon was in error, therefore, when citing the lack of interest in Nietzsche expressed by the generation of 1912. Rather, while Agathon and some nationalists rejected all German influences out of principle, the role of Nietzsche in French letters increased dramatically after 1900 - a phenomenon made possible only through the intellectual reorientation effected by their elders.

The writers who comprised the intellectual generation of 1890 were born between 1860 and 1870 and thus were between twenty and thirty years old by 1890. As Claude Digeon points out, what is striking about many of this generation is their apparent indifference to the defeat of 1870-71. As members of the first "republican" generation in France, many saw Napoleon III and the Franco-Prussian War as the experiences of their elders and none of their concern. ${ }^{6}$ Many agreed that the primacy of France in the world arena had been decisively ended by the defeat and that the Third Republic formed soon after would, due to numerous political scandals, collapse at any time. This perceived lack of energy and will resulted in the resignation to and even the glorification of "decadence."7 An attitude of systematic detachment manifested itself most visibly in the literary school of Symbolism, which flourished during the 1880s and counted as its most illustrious practitioners Stéphane Mallarmé, Paul Verlaine, Gustave Kahn, Paul Bourget, Joris-Karl Huysmans, and Philippe Villiers de l'Isle-Adam. As a response to the Naturalism of Emile Zola and Guy de Maupassant, Symbolism offered its adherents a conception of the world and a state of mind which would pervade much of French literary life. Positing the absurdity of political action and the inevitable suffering of human existence, the Symbolists rejected external reality in favor of a new kind of idealism, which in its variety of forms included solipsism, occultism, mysticism, and a fascination with the morbid. Paramount to this movement was the artists' resolve to flee reality through a variety of means, such as hallucinatory drugs, dreams, or other altered states of mind. Finally, the decadent Symbolists refused to participate in political and social life, arguing instead for the detached position of "l'art pour l'art."8

${ }^{6}$ Claude Digeon, La Crise allemande de la pensée française (1870-1914) (Paris, 1959), 384-86.

${ }^{7}$ Eugen Weber, France, Fin de Siècle (Cambridge, Mass., 1986), 11, 107, 110-14.

${ }^{8}$ Symbolism as a literary movement was born with Jean Moréas' symbolist manifesto, which appeared in the 18 September 1886 issue of. Le Figaro. Cf. Bonner Mitchell, Les Manifestes littéraires de la belle époque, 1886-1914 (Paris, 1966), 23-32; Jean Pierrot, The Decadent Imagination, 1880-1900 (Chicago, 1981), 239-40; Raymond Rudorff, Belle Epoque: Paris in the Nineties (London, 1972), 119-21. 
Most important to Symbolist literature was Richard Wagner, whose music and writings would elevate him to the status of a cult figure in Paris during the $1880 \mathrm{~s}$ and $1890 \mathrm{~s}$. While the operas of Wagner maintained their popularity throughout the fin de siècle, these did not capture the interest of these writers; in fact, few Symbolist writers possessed any considerable knowledge of his music. As Adolphe Retté noted, paraphrasing Nietzsche: "it is not with music that Wagner had carried away the young people, it is with the idea." Wagnérisme was seen as an extreme idealism which, by advocating aesthetic escape into legends and mythology, provided the primary imagery for decadent literature and art. Three of the composer's disciples, Edouard Dujardin, Téodor de Wyzewa, and Houston Stewart Chamberlain, formed the Revue wagnérienne in 1885 , the chief organ of French Wagnerism. Both Dujardin and Wyzewa were important theoreticians of Symbolism, and the latter translated Wagner's essays for Stéphane Mallarmé, the high priest of Symbolism and a great admirer of the composer. ${ }^{10}$ From the start links were made between Wagnerism and this literary movement, and even the editor of La Revue wagnérienne, Dujardin, noted in the late 1880 s that Wagner's conception of the soul "had been exactly that which Mallarmé and the symbolists had made of poetry." In a collective "Hommage à Wagner" the brightest stars of French Symbolism, including Mallarmé, Paul Verlaine, and René Ghil, professed their faith to the "god Wagner."12

Although the Revue wagnérienne collapsed in 1888 due to internal tensions, provoked primarily by its financial supporters' desire to dissociate the journal from the decadents, ${ }^{13}$ by 1891 Wagner was still popular in France-the year when Nietzsche made his debut among Parisian intellectuals. André Billy notes that 1891 also marked the apogee of French decadence, ${ }^{14}$ after which would ensue the crumbling of the Symbolist edifice due to several counter-tendencies and political crises, most importantly anarchism and the Dreyfus Affair, which would rouse intellectuals from detachment to political engagement. The advent

${ }^{9}$ Adolphe Retté, “Sur Nietzsche," La Plume, 1 September 1898 (9), 517; see also Frédéric Nietsche [sic], "Le Cas Wagner" tr. Daniel Halévy et Robert Dreyfus, La Société nouvelle, 15 (Jan.-Feb. 1892), 136; and André Coeuroy, Wagner et l'esprit romantique (Paris, 1965), 25152.

10 Stéphane Mallarmé, "Richard Wagner: réverie d'un poète français" La Revue wagnérienne, 1 (8 Aug. 1885), 195-200; Henri de Régnier, De mon temps. . . (Paris, 1933), 108; Gerald D. Turbow, “Art and Politics: Wagnerism in France” in David C. Large and William Weber (eds.), Wagnerism in European Culture and Politics (Ithaca, 1984), 160-61; Elga Liverman Duval, Téodor de Wyzewa: Critic Without A Country (Paris, 1961), 28-29; André Billy, L'Epoque 1900 (Paris, 1951), 93; Eugenia W. Herbert, The Artist and Social Reform: France and Belgium, 1885-1898 (New Haven, 1961), 78-79.

"Edouard Dujardin, quoted in Billy, 92.

12 Stéphane Mallarmé et al., "Hommage à Wagner," La Revue wagnérienne, 1 (8 Jan. 1886), 333-42.

${ }^{13}$ Geoffrey C. Field, Evangelist of Race: The Germanic Vision of Houston Stewart Chamberlain (New York, 1981), 67; Edouard Dujardin, “La Revue Wagnérienne," La Revue musicale, (1 October 1923), 157.

${ }^{14}$ Billy, 104. 
of Nietzsche's ideas during this transitional period of the literary field partly accounts for the end to which his thought was wielded - that is, as a weapon against decadence - and at the same time ithighlights the transformation of the field itself.

When considering the proliferation of the ideas of Schopenhauer, Wagner, and Nietzsche in Europe at the fin de siècle, it is important to note the difference between France and other countries. The young intellectuals of Austria and Russia, for example, received the early writings of Nietzsche first; and because these works lauded both Wagner and Schopenhauer, they were easily incorporated into their cultural programs. The members of the "Pernerstorfer Circle" and the "Telyn Society" in Vienna read Nietzsche's early works shortly after publication in the 1870s and even drafted a group letter to the philosopher. Even after Nietzsche's break with Wagner and his denunciation of the composer in his later writings, many of these young Austrians tended to interpret these later works within the framework of his earlier praise of Wagner. While some would of course follow Nietzsche in his rejection of the composer, many would retain the idea of a Schopenhauer-Wagner-Nietzsche triumvirate.$^{15}$ Similarly, in Russia during "The Silver Age" (1890-1917) the ideas of Nietzsche were often associated with those of Wagner despite the fact that the polemical Case of Wagner was his first work to be translated into Russian in $1894 .{ }^{16} \mathrm{Hence}$, in these countries the Wagner-Nietzsche break was not keenly felt and was evenignored by those who had favorably received the early writings.

This was not the case in France. Indeed, while the first of Nietzsche's works to be translated was the laudatory "Richard Wagner in Bayreuth" (1877), this authorized translation by the Alsatian Marie Baumgartner attracted little attention outside of a small circle of Swiss Wagnerians ${ }^{17}$ and contained nothing that could displease a member of the Wagner cult. Among French Wagnerians during the 1880 s the ideas of Nietzsche played no significant role and may even have been discouraged by the English Germanophile Houston Stewart Chamberlain, who was a cofounder of La Revue wagnérienne. A fervent disciple of Wagner and later known for his proto-Nazi racial theories, Chamberlain regularly visited Bayreuth and later married the composer's daughter. It is likely that he had met Nietzsche at Bayreuth and during the 1880 s may have even been familiar with his works - especially with his split with Wagner. Given his attachment to Wagner, his later hatred of Nietzsche, and his influential position within French Wagnerism, it is plausible that Chamberlain would have coun-

is William J. McGrath, Dionysian Art and Populist. Politics in Austria (New Haven, 1974), 2, 54, 60, 69-70, and 89.

${ }^{16}$ Bernice Glatzer Rosenthal, "Wagner and Wagnerian Ideas in Russia" in Large and Weber (eds.), Wagnerism in European Culture and Politics, 198-99, 202, and 204; Rosenthal, Nietzsche in Russia (Princeton, 1986), 30-31; Richard D. Davies, "Nietzsche in Russia, 18921919: A Chronological Checklist" in Rosenthal, Nietzsche in Russia, 357.

${ }^{17}$ Geneviève Bianquis, Nietzsche en France (Paris, 1929), 4; Nietzsche, Richard Wagner à Bayreuth, tr. Marie Baumgartner (Schloss-Chemnitz, 1877). 
seled his colleagues against a serious consideration of Nietzsche's writings. Another possible agent of discouragement may have been Edouard Schuré, a French literary critic and Wagnerian who had met Nietzsche at Bayreuth in 1876. Unlike other Wagnerians who later renounced their youthful faith, Schuré remained indignant about Nietzsche's heresy and explained the philosopher's insanity and violent philosophy as the necessary result of his break with Wagner. ${ }^{18}$ That either Chamberlain or Schuré actually counselled French Wagnerians against studying Nietzsche is of course pure conjecture. However, the factstands that Nietzsche remained unknown to most Parisians until Téodor de Wyzewa's 1891 article - in the midst of a structural shift of the French literary field away from decadence. ${ }^{19}$

The first translated book by Nietzsche to have a significant impact on French intellectual circles was a venomous diatribe against the composer, Der Fall Wagner. Here the French found not the unmitigated praise of "Richard Wagner in Bayreuth," but a virulent rejection of the composer as a major source of contemporary decadence. In addition, the translated fragments of Nietzsche's texts which appeared thereafter were almost exclusively excerpted from the later writings, such as Also sprach Zarathustra, Jenseits von Gut und Böse, Nietzsche contra Wagner, and Der Antichrist, all published after the break with Wagner. As such, the introduction of Nietzsche to the French effected a rupture with the Wagnerian "church" rather than the continuity found in other countries, and this break would by implication undermine one of the foundations of decadent Symbolism as well. ${ }^{20}$

Two literary events in 1892 hint at the burgeoning mood in the French literary field and dealt very decisive blows to Symbolism and to the Wagner

${ }^{18}$ Dietrich Fischer-Dieskau cites a letter from Edouard Schuré to Wagner of 1881 where the former describes Nietzsche's new attitude as "heart-breaking nihilism." Fischer-Dieskau, Wagner and Nietzsche (New York, 1976), 175; Cf. Edouard Schuré, "L'Individualisme et l'anarchie en littérature: Frédéric Nietzsche et sa philosophie," Revue des dewx mondes, 130 (15 Aug. 1895), 782-84; for a later attack on Nietzsche see Schuré, "Nietzsche en France et la psychologie de l'athée," La Revue bleue, 14 (8 September 1900), 289-95; Eric Hollingsworth Deudon, Nietzsche en France: L'Antichristianisme et la critique (Washington, D.C., 1982), 4549.

19 There were, however, several French writers who were familiar with Nietzsche and his writings before 1891 . For example, the writer Alfred Jarry claimed that his lycee professor at Rennes, Benjamin Bourdon, taught the ideas of Nietzsche as early as 1889 . In addition, the historian Hyppolite Taine and the writer Jean Bourdeau both corresponded with Nietzsche in 1888 concerning possible French translations of his works. Bourdeau, who had already translated selections from Schopenhauer's work, informed Nietzsche that his friend (Gabriel?) Monod had read and recommended Jenseits von Gut und Böse. Finally, shortly before his collapse in Turin, Nietzsche wrote two apparently unsolicited letters to the novelist Catulle Mendès, neither of which were answered. Cf. Henri Béhar, Les cultures de Jarry (Paris, 1988), 82, 197; Nietzsche Briefivechsel (Berlin, 1984), 1I1(5), 511, 532-36, 556, 570-71; 111(6), 38687, 403, 418-19.

${ }^{20}$ Nietzsche's reception in England is also worth mentioning, for here as in France the split with Wagner proved decisive for the philosopher's future notoriety. Cf. David S. Thatcher, Nietzsche in England, 1890-1914 (Toronto, 1970), 178-80. 
church in France: the inaugural issue of the ephemeral avant-garde journal $L e$ Banquet and the French translation of Der Fall Wagner. These two publications, produced by the same group of young writers, were most clearly responsible for the Nietzsche vogue which followed, and both lucidly articulated the regeneratory rhetoric which would accompany later commentaries on Nietzsche.

Le Banquet was formed in 1892 by several graduates of the Lycée Condorcet, the most prestigious of the right-bank schools. The leader of this literary coterie was Daniel Halévy, and grouped around him were Fernand Gregh, Robert Dreyfus, and Marcel Proust. In addition to this circle from Condorcet were several from the Lycée Henri IV, most notably Léon Blum. While the journal was dedicated to theirteacherand discussion leader, Mallarmé, the direction that the magazine chose seemed at odds with the Symbolist program; in fact Mallarmé and his fellow Symbolist Paul Verlaine had inspired the young littérateurs to set out on their own rebellious directions. ${ }^{21}$ Robert Dreyfus recalled that $L e$ Banquet, despite the dedication to Mallarme, had been "founded in reaction against symbolism" and that one of its chief aims was to "renew the pure and rich French tradition by an intelligent fusion of classicism and romanticism." "Enough of Shakespeare," Dreyfus declared in an early article for Le Banquet, "enough of Ibsen, enough of Tolstoy, enough of [Maurice] Maeterlinck. Let us return to France, the devil!"22 Presumably impressed by Nietzsche's effusive praise of French culture, Dreyfus suggested the writings of the German thinker for his "return to France." In the eyes of the Symbolists, Fernand Gregh remembered, "we seemed a bit like heretics. The literary public had gone to the great [Symbolist] church of the MercuredeFrance and neglected our little chapel." ${ }^{23}$ Hence, an attack on the Symbolist establishment was one of the primary aims of these writers, an end for which they effectively used the ideas of Nietzsche. ${ }^{24}$

In the April 1892 issue of Le Banquet, Halévy and Gregh presented an article entitled "Frédéric Nietzsche," a ringing defense of the philosopher against the first French commentators whom they believed had grossly misrepresented and distorted his ideas. ${ }^{25}$ The article with which the young men were most angry was "Frédéric Nietzsche, le dernier métaphysicien," written by the well-known literary critic and German specialist, Téodor de Wyzewa. ${ }^{26}$ Writing in the conservative journal La Revue bleue, Wyzewa pointed out that while Nietzsche was one of the best writers of the German language, he was nonetheless a nihilist

${ }^{21}$ Alain Silvera, Daniel Halevy and His Times (Ithaca, 1966), 41-43, 57.

${ }^{2}$ Robert Dreyfus, Souvenirs sur. Marcel Proust (Paris, 1926), 106-7.

${ }^{23}$ Fernand Gregh, L'Age d'or: souvenirs d'enfance et de jeunesse (Paris, 1947), 153.

${ }^{24}$ Jean-Michel Place and André Vasseur, "Le Banquet" in Bibliographie des revues et journaux littéraires des XIXe et XXe siècles (Paris, 1973), 196-97; Dreyfus, Souvenirs, 106-7.

${ }^{25}$ Daniel Halévy and Fernand Gregh, "Frédéric Nietzsche" Le Banquet (April 1892), 3335.

${ }^{26}$ Téodor de Wyzewa, "Frédéric Nietzsche, le dernier métaphysicien," La Revue bleue, 48 (7 November 1891), 586-92. 
who delighted only in destruction. "Nothing," Wyzewa wrote, "there has never been anything, there is never anything, and there never will be anything: such is, in one phrase, the philosophy of Nietsche [sic]." ${ }^{27}$ Like the Russian nihilist Bazarof, Wyzewa contended, Nietzsche was born without illusions, and with "an imperious need to destroy, ... [and] to simultaneously laugh and cry over what he had destroyed." Never "in the entire history of human thought" has there been such a destroyer. ${ }^{28}$ Despite this provocative presentation of Nietzsche as a pessimist and a nihilist, Wyzewa did make a very acute prophecy that would be borne out shortly after the publication of his article:

In France, no one knows him; but I feel certain that [on] the day when he will be known, his action will be as lively, and his renown as strong as in other countries. For the French youth, unhappy with the gods which had satisfied its elders, aspires towards an unknown god; and no one as much as Nietsche [sic] has the qualities which are best-suited to fill this office. ${ }^{29}$

This article also marked the first of a series of essays which Wyzewa would devote to Nietzsche over the next several years. ${ }^{30}$ In these writings Wyzewa always retained bitter skepticism, if not outrighthostility, toward the ideas of the German. At the end of his life would disclose to his daughter that Nietzsche was the cause of all the ills of the Western world. ${ }^{31}$

Halévy and Gregh rejected Wyzewa's characterization of Nietzsche as a pessimist, asserting rather that "he is the philosopher of confidence, of health, ofjoy." Several journals had already written about the philosopher, the authors conceded, "but those who have spoken have hardly read him. The most substantial of the articles ... that of M. Téodor de Wyzeva [sic], should be considered null and void: he has greatly surprised those who have known Nietzsche." ${ }^{32}$ What is worse, the authors continued, Wyzewa's erroneous view of Nietzsche had misled other commentators, causing greater confusion. Camille Bellaigue's article on Nietzsche, ${ }^{33}$ they claimed, was informed only by the interpretation of Wyzewa, "that is to say less than not at all, [but] falsely." ${ }^{34}$

${ }^{27}$ Wyzewa, "Frédéric Nietzsche, le dernier métaphysicien," 592.

${ }^{28}$ Ibid., 587, 588.

${ }^{29}$ Ibid, 586.

${ }^{30}$ Téodor de Wyzewa's articles on Nietzsche since 1891 include: "Le dernière oeuvre de Frédéric Nietzsche," Le Temps, 3 (5 Dec. 1894; "Les écrits posthumes d'un vivant," Le Temps, 2 (7 Dec. 1895); "Frédéric Nietzsche et le culte de Bismarck," Le Temps, 2 (21 Dec. 1898); "Documens nouveaux sur Frédéric Nietzsche," Revue des deux mondes, 154 (15 July 1899), 453-62.

${ }^{31}$ Duval, 86n.

${ }^{32}$ Halévy and Gregh, "Frédéric Nietzsche," 33.

${ }^{33}$ Camille Bellaigue, "Un problème musical," Revue des deux mondes, 62 (1 March 1892), 221-27.

${ }^{34}$ Haiévy and Gregh, "Frédéric Nietzsche," 34-35. 
These distorters of Nietzsche's message had obscured the optimism at the heart of his doctrine, which was embattled against the decadence prevailing in modern culture:

There is an aesthetic of decadence, born of the decadent moralities, and which it is necessary to combatas such. This aesthetic is that of Wagner. Nietzsche had believed in Wagner so much that he had been a Schopenhauerian; but from the day when his eyes opened to life and he regained confidence before nature, the music of Wagner appeared to him as a public menace..$^{35}$

Wagner represented the "decadent type" and by implication the Symbolist world view, which had renounced reality for mystical inner states. In opposition to this, Halévy and Gregh wrote, Nietzsche preached the affirmation of life "initself, to accept life wholly, and to live it as completely, as richly as possible."36

That these writers responded so emphatically to Wyzewa's portrait of Nietzsche obviously suggests that the philosopher was being read in France well before 1891. In fact it is probable that the editors of Le Banquet became acquainted with Nietzsche through their contact with the Belgian Société nouvelle, the first francophone periodical to present translations of Nietzsche's writings. ${ }^{37}$ Robert Dreyfus remembered years later that the first Le Banquet article on Nietzsche created a sensation in Parisian literary circles, offering "the first glimpses received in France on the poet-philosopher, whose originality immediately seemed so robust and so moving." 38 In Nietzsche an alternative to decadent symbolism was offered, a philosophy of vitality and action rather than impotence and escape. The following month Robert Dreyfus contributed his own essay about "the mortal enemy of Richard Wagner," where he continued the attack on Wyzewa and stressed the optimism of the German philosopher. "Frédéric Nietzsche has spent his staunch life struggling against nihilism and pessimism," Dreyfus remarked, "What interests us in [him] is the effort he made to withdraw from the first masters of his youth, Wagnerand Schopenhauer."

${ }^{35}$ Halévy and Gregh, "Frédéric Nietzsche," 34.

${ }^{36}$ Ibid.

${ }^{37}$ La Société nouvelle first published Halévy and Dreyfus's translation of Der Fall Wagner, as well as other translations of and commentaries on Nietzsche's work. Cf. Nietzsche, "Le Cas Wagner" tr. Daniel Halévy et Robert Dreyfus, La Société nouvelle, 1 (Jan.-Feb. 1892), 117-47; “Ainsi Parla Zarathustra" tr. W. P., La Société nouvelle, 1 (April 1892), 390-401; "Dithyrambes et Dionysos" tr. Georges Mesnil, La Société nouvelle, 1 (June 1892), 744-50; “L'Antéchrist," tr. Henri Albert, La Société nouvelle, 7 (Jan. 1895), 87-104; (Feb. 1895), 208-22; (March 1895), 390-99; (May 1895), 657-71; (June 1895), 778-84; Georges Dwelshauvers, "Etudes sur Friedrich Nietzsche," La Société nouvelle, 2 (Oct. 1892), 470-81.

38 Dreyfus, Souvenirs, 79. This brief article in Le Banquet introduced two translated fragments of Beyond Good and Evil, which were the first of Nietzsche's writings to be published in Paris since 1877. Cf. Frédéric Nietzsche, "Au delà du bien et du mal," tr. Daniel Halévy and Fernand Gregh, Le Banquet, (April 1892), 36-40. 
In The Twilight of the Idols, one of Nietzsche's last works, Dreyfus found a "grand declaration of war [emphasis in original]" against the old idols of decadence and pessimism, a critique which Dreyfus was able to apply to his own time. "The error of Mr. de Wyzewa consists in confusing historical pessimism ... with philosophical pessimism, which details precisely, according to Nietzsche, the conception of the universe proper to epochs of decadence." 39

Throughout the short life of Le Banquet (less than a year) the journal's staff continued its presentation of the philosophy and biography of Nietzsche as well as the most up-to-date German commentaries on his work. ${ }^{40}$ In fact the devotion with which Le Banquet conducted its mission to introduce Nietzsche to a French audience was surpassed only by that of Henri Albert and the Mercure de France, who together published the collected writings of Nietzsche in French. While the literary impact of Le Banquet was slight, it is indicative of a counter-movement in French letters. Aligned with the ideas of the conservative Maurice Barrès in a return to traditional French values, if not revanche for the defeat of 1870-71, this tendency toward nationalism and energy would gain momentum as France rushed toward war after 1905, and many of Nietzsche's ideas would be used to help legitimate such nationalism. In an article about Nietzsche's friend Peter Gast, for example,Dreyfus cited Gast's misgivings about the effect of Nietzschean thought in France:

What must one understand by this conception of the Uebermensch? A French romancier, according to [Peter] Gast, would fantasize about making the Overman be born in Alsace, and would have him reconquer Lorraine and Alsace for France. "However much flattery it was for we otherGermans, continues Mr. Peter Gast,... we always continue to wish that a people as full of spirit as our neighbors to the West will not mislead themselves on so small a cost about one of the most grandiose conceptions of humanity."41

Nevertheless, several writers associated with the Action Française did adopt such a nationalistic interpretation of Nietzsche's thought. ${ }^{42}$ After the collapse of Le Banquet in 1893, the avant-garde and engagé journal La Revue blanche absorbed many of the writers into its own ranks, from which Halévy and Dreyfus would publish further translations and studies of Nietzsche. ${ }^{43}$

${ }^{39}$ Robert Dreyfus, "La philosophie du marteau," Le Banquet, (May 1892), 65, 67-68, 69.

${ }^{40}$ F[ernand]. G[regh]., "Varia," Le Banquet, (June 1892), 125-28; "Varia," Le Banquet, (Nov. 1892), 191-92.

${ }^{41}$ Robert Dreyfus, "Frédéric Nietzsche et Peter Gast," Le Banquet (Nov. 1892), 163.

${ }^{42}$ Cf. Reino Virtanen, "Nietzsche and the Action Française: Nietzsche's Significance for French Rightist Thought," JHI, 11 (1950), 191-214.

${ }^{43}$ Gregh, L'Age d'or, 188; L. A. N. "Les revues," La Revue blanche, 20 (April 1892), 24950. Frédéric Nietzsche, "Fragments," tr. Daniel Halévy, La Revue blanche, 3 (Aug.-Sept. 1892), 95-100; 3 (Nov. 1892), 251-60; Daniel Halévy and Robert Dreyfus, "Frédéric Nietzsche: étude et fragments," La Revue blanche, 12 (1897), 57-68. 
The second attack on Wagner and, by extension, on the Symbolist worldview was contemporaneous with $L e$ Banquet and was dealt by two members of its staff, Daniel Halévy and Robert Dreyfus: the first French translation of Nietzsche's Der Fall Wagner (The Case ofWagner). While this translation was originally published in the Belgian anarchist journal, La Sociéte nouvelle, in January 1892, the bound French edition did not appear until later that year. ${ }^{44}$ Nonetheless, Le Cas Wagner created quite a stir among French intellectuals; for whereas the first French rendition of Nietzsche had been the little-noticed essay, "Richard Wagner in Bayreuth" (1877), this second book gained immediate attention for its condemnation of Wagner as a major source of decadence and especially of Wagner's Parisian disciples for propagating his degenerate religion. In fact many cite this work as the first and most devastating critique of Wagner of the time - even Wyzewa called it "the only reasonable product of antiwagnerian literature."45 "My greatest victory," Nietzsche declared in the opening pages, "was a recovery. Wagner is merely one of my sicknesses." ${ }^{" 46} \mathrm{As}$ Schopenhauer had been the philosopher of decadence, Nietzsche wrote, Wagner was its artist. "How closely related Wagner must be to the whole of European decadence to avoid being experienced by them as a decadent. He belongs to it: he is its protagonist, its greatest name.-One raises oneself when raising him to the clouds." 47

After wrecking on the reef of Schopenhauerian pessimism, Nietzsche explained, Wagner identified the wreck as his goal, and adopted the pessimistic attitude in his operas. "Everything goes wrong, everything perishes, the new world is as bad as the old." Across Europe many have deceived themselves about Wagner, but nowhere as seriously or as alarmingly as in Paris: "That people in Germany should deceive themselves about Wagner does not surprise me. The opposite would surprise me... . But that people in Paris, too, deceive themselves about Wagner, though there they are hardly anything anymore except psychologists!"48 The problems that ultimately concerned Wagner, Nietzsche noted with regret, were only those "which preoccupy the little decadents of Paris. Always five steps from the hospital. All of them entirely modern, entirely metropolitan problems. ${ }^{49}$ Nietzsche's understanding of what

${ }^{44}$ Frédéric Nietsche [sic], "Le Cas Wagner," tr. Daniel Halévy and Robert Dreyfus, La Société nouvelle, 15 (Jan.-Feb. 1892), 117-47; Le Cas Wagner, tr. Daniel Halévy and Robert Dreyfus (Paris, 1892).

${ }^{45}$ Wyzewa, "Frédéric Nietzsche, le dernier métaphysicien," 592n; Henri Lichtenberger, "Wagner et l'opinion contemporaine," La Revue musicale (1 Oct. 1923), 80.

${ }^{46}$ Frédéric Nietsche [sic], "Le Cas Wagner," tr. Daniel Halévy and Robert Dreyfus, La Société nouvelle, 15 (Jan.-Feb. 1892), 118; translations appearing here are from Friedrich Nietzsche, The Case of Wagner in Basic Writings of Nietzsche, tr. Walter Kaufmann (New York, 1968), 611.

47 "Le Cas Wagner," 126; The Case of Wagner, 620, 621.

48 "Le Cas Wagner," 125, 126; The Case of Wagner, 621.

49 "Le Cas Wagner," 135; The Case of Wagner, 632. 
most Wagnerians tended to represent was uncannily accurate: "Look at these youths-rigid, pale, breathless! These are the Wagnerians: They understand nothing about music - and yet Wagner becomes master over them." ${ }^{50}$ As Max Nordau would do several years later, Nietzsche identified Paris with the modern - and with the decadent - but Nietzsche proposed a way out for Wagnerians everywhere. As the composer was perhaps a necessary sickness, Nietzsche ventured, overcoming him would result in a renewed vigor and youthfulness: "To sense that what is harmful is harmful, to be able to forbid oneself something harmful, is a sign of youth and vitality.... Sickness itselfcan be a stimulant to life: only one has to be healthy enough for this stimulant."51

Clearly, given Nietzsche's well-known and later exploited love for France, he hoped that a new vitality to end European decadence would take root in Paris. Yet such a cure had to be at the expense of the Wagner cult, Schopenhauerian pessimism, and decadent Symbolism as well. The writers of Le Banquet recognized this and, with the hope of provoking a regeneration in French letters, sustained Nietzsche's attack throughout the short life of the journal. That $\mathrm{Le} \mathrm{Cas}$ Wagner was translated as an assault upon decadence is clearly expressed in Nietzsche's foreword. "Perhaps no one has been more dangerously plunged into wagnérisme than $\mathrm{I} ; . .$. [and] no one has rejoiced more loudly for escaping him."

I am as much as Wagner the Child of the century, that is to say a décadent: with this difference, that I perceived this in myself and assumed a state of defense. ... [I]t was necessary for me to set out in war against all that had been diseased in me-understood as Wagner, as Schopenhauer, and as all modern "Humanity"... . If I emphasize in this writing that Wagner is a dangerous man, I equally stress that he is indispensable to someone:- to the philosopher. ${ }^{52}$

Le Cas Wagner and Le Banquet were both expressions of the growing disenchantment with decadence among French writers-early examples of the more general protest which would erupt around 1900.

The reaction of some writers to Le Cas Wagner was predictable and significant. For example, Camille Mauclair remembered "the rage which seized us after the first translations of Nietzsche, which had interested and even impassioned us." Yet Le Cas Wagner was something different: "[t]his was not the rebellion of the spirit against a doctrine: it was the sting of the offense to an

so "Le Cas Wagner," 131; The Case of Wagner, 628.

S1 "Le Cas Wagner," 126; The Case of Wagner, 621.

${ }^{52}$ Nietzsche, "Avant-propos," Le Cas Wagner (Paris, [1892] 1893), 1-3. Many years later Halevy wrote to his friend Jules Romain regarding his conversion experience: "I discovered the abyss lying beneath a life which seemed so blissful . . . and I became aware of the necessity for a radical change.... I discovered that this wretched literary ambiance, Wagnerian and Tolstoian, in which I had been raised was nothing but a snare, a stage-effect destined to be swept away." MS letter, dated 7 Oct. 1947, quoted in Silvera, 72, n. 53. 
adored creature. Wagner had been for us rather more than a passion, a religion." ${ }^{53}$ After the initial shock of this attack on Wagner, Mauclair went on to espouse more fully Nietzsche's rhetoric of regeneration, if only to apply it to aesthetic individualism. ${ }^{54}$ Léon Daudet, a later spokesman for the Action française, called Le Cas Wagner a masterpiece.$^{55}$ Adolphe Rette, who had taken the idea of social regeneration far more seriously than Mauclair, explained the conflict in less passionate terms:

The Wagnerians took badly Nietzsche's recantation which, after having defended the musical drama, set himself all at once to attack it with a vivaciousness that was not devoid of logic. Some affirm that he wanted to singularize himself, to draw attention to himself at the expense of the Buddha of Bayreuth. Others declare him prematurely insane. ${ }^{56}$

An anonymous editor of the Belgian journal, La Jeune belgique, reviewing the first publication of Le Cas Wagner in La Sociéte nouvelle, noted simply the "frantic incoherence" of this "ridiculous pamphlet," to which one could only respond with "the shrugging of shoulders." ${ }^{\text {" N7 }}$ Nonetheless, the French translation of Der Fall Wagner was indicative of, and contributed to a critique of the tranquil aesthetic of escape which the Wagnerians and many Symbolists exercised - and it appeared at a time when many writers were reconsidering the political role of the intellectual.

The efforts of the writers of Le Banquet and others contributed in mid-1892 to a noticeable Nietzsche vogue in Paris, which accompanied the "culte du moi" call to energy of Maurice Barrès and the politicization of the literary field. Not all commentators were pleased with this development, however: in April 1892, for example, one writer stated that "I consider criminal the philosophers such as Nicht [sic], who declare: there is nothing." ${ }^{88}$ In May of that year La Jeune belgique noted with disgust that "Nietzsche continues to make pens scratch... Sad, sad!"s9 By June La Revue jeune noted the existence of "Nietzschisme" in France, to which a surprised reviewer from La Revue blanche responded:

${ }^{53}$ Camille Mauclair, Servitude et grandeur litterraires (Paris, 1922), 225. The translations cited by Mauclair were presumably those which appeared in Le Banquet and La Sociéte nouvelle in 1892.

${ }^{54}$ Herbert, 142-43.

ss Léon Daudet, Souvenirs: des milieux littéraires, politiques, artistiques et médicanx (Paris, 1920), 425.

56 Adolphe Retté, "Sur Nietzsche," La Plume, 9 (1 Sept. 1898), 517.

57 "Memento," La Jeune belgique, 11 (Feb. 1892), 163.

58 Crayon d'Or, "Pour les femmes," Le Figaro (16 April 1892), 2.

s9 "Memento," La Jeune belgique, 11 (May 1892), 227; in addition, an observer for La Société nouvelle noted incredulously that "La Gazette of Brussels declares that the German philosopher Nietsche [sic] is absolutely unknown in Belgium!!!!" Cf. "Le mois," La Sociéte nouvelle, 1 (March 1892), 375. 
"already!"60 This attraction to the ideas of Nietzsche manifested itself primarily among Symbolist writers swept up in the anarchist wave of the early 1890s and who as a result were able to apply the ideas of Nietzsche to their new political consciousness. Nietzsche was seen by many as an antidote to the vogues of Tolstoy, Ibsen, Schopenhauer, and Wagner during the heyday of Symbolism in the $1880 \mathrm{~s} .{ }^{61}$ Even Léon Daudet recalled that Nietzsche had "exhausted a certain number of neo-Buddhists, I mean Tolstoyans and Ibsenians; he has distracted them for several years from [their] non-resistance and from their navels."

For many young French writers, as demonstrated above, the ideas of Nietzsche proved a useful weapon with which to undermine the Symbolists and their Wagnerian attachments to decadence. It will also be shown that many writers adopted the ideas and inflammatory language of Nietzsche in a positive way: to articulate their desire for vital and life-affirming action, exemplified especially in literary anarchist circles, among certain radical conservative elements, and within the chieforgan of the changing Symbolist movement itself, the Mercure de France. The common denominator for these various groups was the stress on cultural regeneration, for which Nietzsche's thought became an important and perhaps dangerous catalyst.

French writers who immediately espoused certain aspects of Nietzsche's thought were the literary anarchists - propagandists of the idea of untrammeled individual liberty rather than the deed of anti-bourgeois violence. Many Symbolists enlisted in the anarchist program, suggesting their turn from pessimistic flights of fantasy to political involvement. That the "liberty" these writers most often advocated was pure artistic freedom, expressed only on paper, does not necessarily undermine the cited intellectual shift toward rejuvenation: whatever their motivations were, the call for regeneration was still a clear attempt to escape decadence, even if these issues and final goals were themselves aestheticized.

Several literary anarchists during the 1890 s imbibed the philosophy of Nietzsche. The anarchistLaurent Tailhade, infamous for his nonchalance about the victims of anarchist violence "as long as the gesture is beautiful," is said to have been a Nietzschean. Camille Mauclair considered himself to be both a Nietzschean and an anarchist, even though his political commitment to social causes may be doubted. ${ }^{63}$ Even the literary anarchist Jean Grave, while certainly

${ }^{60}$ Cf. N. "Les revues," La Revue blanche, 2 (June 1892), 383; Georges Valbert, "Le Docteur Friedrich Nietzsche et ses griefs contre la société moderne," Revue des deux mondes, 113 (1 Oct. 1892), 677-89; Jean Bourdeau, "Nouvelles modes en philosophie: Le néo-cynisme aristocratique-Frédéric Nietzsche," Journal des débats (20 April 1893), 1-2; Louis Stein, "Frédéric Nietzsche: l'homme et l'écrivain," La Revue bleue, 2 (9 Dec. 1893), 748-51.

${ }^{61}$ Richard D. Sonn, Anarchism and Cultural Politics in Fin de Siècle France (Lincoln, 1989), 219; Pierrot, The Decadent Imagination, 240, 253; see also Adolphe Retté, Le symbolisme: anecdotes et souvenirs (Paris, 1983 [1903]), 237.

${ }^{62}$ Daudet, 426.

${ }^{63}$ Roger Shattuck, The Banquet Years: The Origins of the Avant-Garde in France, 1885 to World War I (London, 1969), 20-21; Herbert, 142-43. 
no great admirer of the philosopher, early in the 1890s drew parallels between Nietzsche's ideas and those of anarchism. This comparison, however, he would grow to regret - in years to come so many anarchists associated themselves with Nietzschean individualism that Grave was obliged to issue this statement, which he reiterated in several later texts: "[w]ithout a doubt, well before the bourgeois littérateurs had discovered Nietzsche and [Max] Stirner, several anarchists had found that the 'Individual' had only to consider his own 'Self,' his own comfort, [and] his own development." 64 Grave questioned the commitment of those writers who, because they could "recite by heart some passages of Nietzsche or Stirner," of Grave's remarks suggest the penetration of the ideas of Nietzsche among literary anarchists.

Few writers in the 1890 s, except in rare instances, wrote extensively on the role of Nietzsche in anarchism; yet the association of Nietzsche with the movement is made clear by observers. Jean de Nethy was one of these exceptional writers who, early in 1892 declared the philosophy of Nietzsche to be an "aristocratic anarchism." Only after his recovery from Wagner and Schopenhauer, Nethy explained, did the philosopher's real work "through which he dreamed of reforming society" truly begin. ${ }^{66}$ It is significant of the shift away from decadent detachment in French letters that Nethy and writers like him stressed the potential for social change within Nietzsche's work. While Wyzewa did well by introducing Nietzsche to a broader French public, Nethy wrote, he made the mistake of affiliating his work with "the current pessimistic and nihilistic philosophy, which Nietzsche held in horror." in a state of "general decadence," and the work of Nietzsche is "in cruel disharmony with these present tendencies." ${ }^{\prime 68} \mathrm{He}$ teaches "the supreme instinct of life, of action, and repressed power" and calls for a new aristocracy which will counter the levelling tendencies of socialism. ${ }^{69}$ This return to regeneration, it must be noted, also implied a new patriotism, as is contained in the passage from Also sprach Zarathustra that Nethy chose to reproduce: "[O]h my brothers, do not look behind you any more, but only forward! Love the country of your children: this love will be your noble future! and through your children you will pardon yourselves for having been the sons of your fathers!"70 Perhaps indicative of Nethy's subtle nationalist agenda is the omission of this line from the quotation: "Exiles shall you be from all father- and fore-father lands!"71 For

${ }^{64}$ Jean Grave, Quarante ans de propagande anarchiste (Paris, 1973), 385-86.

${ }^{65}$ Jean Grave, "Le Syndicalisme dans l'émancipation sociale," La Société nouvelle, 27 (Oct.-Nov. 1907), 170.

${ }^{66}$ Jean de Nethy, "Nietzsche-Zarathustra," La Revue blanche, 2 (April 1892), 207.

${ }^{67}$ Ibid., 206.

${ }^{68}$ Ibid., 211.

${ }^{69}$ Ibid., 210, 211.

${ }^{70}$ Nietzsche quoted in ibid., 211.

"Nietzsche, "Von alten und neuen Tafeln," Also sprach Zarathustra (Munich, n.d.), 157. 
many French writers, regeneration, nationalism, and Nietzschean thought seemed to go hand in hand, and all three had their immediate roots in the highly charged atmosphere of the early 1890 s.

The role of Nietzsche's ideas among literary anarchists was stressed by many writers-especially his opponents-even though few anarchists elaborated on this association. In 1893 Jean Thorel noted that Nietzsche was, along with Bakunin and Stirner, one of the "fathers of anarchism," an intellectual progenitor of the "explosions, searches, arrests, trials, [and] condemnations" of $1892 .{ }^{72}$ Reflecting upon the anarchist period of the early 1890 s another writer predicted that "history will later say that at the moment when the books of Friedrich Nietzsche were distributed, an entire generation of fanatics took revenge on social inequalities through crime and murder attempts [les attentats] by dynamite."73 And yet several writers of a more conservative bent also perceived in Nietzsche an inspiration for future action. Considering the most threatening "evils" of modern society to be pessimism and socialism, they found in the German an effective remedy for both. ${ }^{74}$

Two notable examples are Henri Mazel and Hugues Rebell, both associated with the avant-garde journal $L$ 'Ermitage.$^{75} \mathrm{Mazel}$, the journal's editor, noted the decadence of French society and the cure which he believed Nietzsche could provide: “[I]f philosophical as well as organic products contain an active principle, the Nietzschean sort could be one of the most powerful agents of social therapy, at once terrible and beneficial. Our time needs it, and in energetic doses."76 Parliamentary socialism was attacked by many in France, mostly because its emphasis on equality and its rejection of revolutionary violence were seen as a celebration of mediocrity and laziness. "We are all cowards," Mazel remarked; on the contrary humanity should be "like nature, pitiless to the weak." Yet this "hideous socialism" is what provoked such humanitarian weakness and what Nietzsche fought most passionately against." "We are cowards, rascally and spiteful," Mazel asserted, "the fine meal for Nietzschean crocodiles!"78

The society of which Nietzsche dreamed, Mazel claimed, "will be the most unstable of all, and destined, like a fire, to flame up and to disappear."79 Yet for

7 Jean Thorel, "Les Pères de l'anarchisme: Bakounine, Stirner, Nietzsche," La Revue bleue, 51 (15 April 1893), 449.

${ }^{7}$ H. Fierens-Gevaert, La Tristesse contemporaine (Paris, 1899), 178-79.

74 Théophile Droz, "La Revanche de l'individu: Frédéric Nietzsche," La Semaine littéraire (3 Nov. 1894), 518.

75 The political sympathies of Henri Mazel and Hugues Rebell are illustrated by their contributions to an 1893 survey of artists and writers regarding the best form of social organization. In this Mazel emerged as an advocate of moderate constraint and solidarity, whereas Rebell was characterized as a partisan of extreme constraint, of an "aristocratic tyranny." Cf. "Un référendum artistique et social," L'Ermitage, 7 (July 1893), 13, 17, 22-23.

${ }^{76}$ Henri Mazel, "Nietzsche et le présent," L'Ermitage, 6 (Feb. 1893), 81.

7 Ibid., 84.

${ }^{78}$ Ibid., 85.

${ }^{79}$ Ibid., 84. 
Mazel this instability and ephemerality was most desirable, filled with the heroism and action which had been lost to modern people raised on the democratic ideal. Mazel's friend, Hugues Rebell, expressed a similar disgust with contemporary society, but posited a different solution. Rather than liberty, Rebell advocated constraint, an orderly society where the weak and common are subordinated to a strong aristocracy. "Frédéric Nietzsche," he wrote in early 1893 , "is truly the man necessary for our directionless and unprincipled society, which has lost its good sense. He has everything with which to conquer young spirits-the disarming jestery and the magnificent inspiration which seduces and transports. $" 80$

Rebell, who had been a Symbolist in the 1880s, attacked the decadence of his contemporaries in 1893 and started to articulate the regeneratory rhetoric which flourished in the 1890s. What Rebell also demonstrated was a marked enthusiasm for Nietzsche, whose work he translated for L'Ermitage and about whom he wrote several essays. ${ }^{81} \mathrm{He}$ even prefaced one translation with his belief in the usefulness of Nietzsche's ideas for "this epoque of equality and base socialism." ${ }^{82}$ Like many writers of his generation, Rebell became caught up in the wave of nationalism after 1900 , which only strengthened his resolve for the regeneration of France through means of constraint. In addition, while Rebell had been clearly enamored with Nietzsche during the 1890 s, by 1905 he renounced his youthful enthusiasm as he moved closer to the monarchism of Charles Maurras. ${ }^{83}$ Such a nationalism may explain the stance of Henri Massis and Alfred de Tarde (Agathon), who also denied the important influence of Nietzsche on French rightist thought: while the ideas of Nietzsche were clearly important, they conceded, as a German he could not be cited as an inspiration-hence the stress on Stendhal as a substitute.

Finally, the initial call for regeneration was manifested most markedly in what was considered the principal organ of Symbolism, the Mercurede France. Launched in 1890 by Alfred Vallette, it was decided after much discussion that the journal would be Symbolist but not decadent. In fact one of the ideals of the Mercure was the preservation of the intellectual independence of its contributors, many of whom reflected the new political consciousness of the $1890 \mathrm{~s}^{84}$

${ }^{80}$ Hugues Rebell, “Le Cas Wagner, par Frédéric Nietzsche," L'Ermitage, 6 (Jan. 1893), 67. For a later extremist version of the appropriation of Nietzsche for authoritarianism see: Georges Valois, L'Homme qui vient: philosaphie de l'autorité (Paris, 1906).

${ }^{81}$ Cf. Pierrot, 240; Frédéric Nietzsche, "De l'homme supérieur," tr. Ph. Otten et Hugues Rebell, L'Ermitage, 6 (April 1893), 263-71; "De la vertu qui rapetisse," tr. S. Brandeis and Hugues Rebell, L'Ermitage, 8 (Feb. 1894), 65-70; Hugues Rebell, "Le Cas Wagner, par Frédéric Nietzsche," L'Ermitage, 6 (Jan. 1893), 66-72; "Sur une traduction collective des oeuvres de Nietzsche," Mercure de France, 13 (Jan. 1895), 98-102.

${ }^{82}$ Rebell et Otten, "De l'homme supérieure," 263.

${ }^{83}$ Georges Le Cardonnel et Charles Vellay, La Littérature contemporaine (1905) (Paris, 1905), 109; Cf. also Charles Maurras, 'Enquête sur la monarchie (Paris, 1900), 145-46; Virtanen, 195-96.

${ }^{84}$ The Mercure de France was one of several jeunes revues to emerge around 1890-and one of the most politically reserved. It nevertheless shared with these other periodicals-such 
What is most striking about this journal is that, aside from the efforts of the youthful staff of Le Banquet, it was the first and most prominent of les jeunes revues actively and consistently to propagate the ideas of Nietzsche during the early 1890s and especially after 1900. The Mercure published numerous essays about the philosopher and, under the guidance of the Germanist Henri Albert, undertook the translation of the complete works of Nietzsche in 1894.

Through his numerous essays, translations, and book reviews, Henri Albert virtually became the high-priest of Nietzsche studies in France. Indeed, evidence of Albert's enthusiasm for Nietzsche may be found as early as 1892, when, in a review of a work by Max Klinger, he claimed that "one bows before [Klinger] as one bows before Nietzsche, full of admiration although often without understanding." 85 By 1893 Albert's admiration was expressed in several essays in the Mercure, where the philosopher was consistently referred to as "the master" or "the teacher." In these essays some insight is offered into the increasing popularity of Nietzsche among the French youth: "Everyday, the army of disciples and imitators augments itself," Albert declared in January 1893, "these satellites which gather around the master and nourish themselves with his thought." "Professors and 'philistines' see with terror the intellectual youth flock in crowds to the sources of his teachings, and I know of a certain university town, one of the more 'enlightened ones,' where his name has still only penetrated to excite the horror and dread of the "honnêtes gens." "86 Albert saw in Nietzsche a "future religion" which had found many converts among the young writers of the 1890 s.

As with many interpreters of this period, Albert's description of Nietzsche had a clearly leftist political bias. Rather than the pure aesthetic revery of the decadents, Albert depicted the German as an "intuitive visionary of the future, Nietzsche the liberator!"87 The "common people," the "populace," the "rabble" whom Nietzsche so adamantly detested, Albert explained, is actually the "desperate middle class, the bourgeois platitude, well-fed and satisfied." If he had approached the poor, the weak, the outcasts, "the martyrs of labor, the true people, perhaps he would have predicted what abundant force for the future still slept in them. ${ }^{" 88}$ Like many intellectuals of the time, including Georges Sorel,

as La Plume, L'Ermitage, La Revue blanche, and 'Entretiens politiques et littéraires-a rejection of the l'art pour l'art detachment of the established reviews, espousing instead the idea of l'art social. Note this new social attitude in L'Ermitage's "Référendum" of 1893, where intellectuals responded to the question: "What is the best condition of the social Good-a spontaneous and free organization, or a disciplined and methodical one?" Cf. Christophe Charle, Naissance des 'intellectuels' (Paris, 1990), 105-6, 119-23; Sonn, 187-89; Billy, 94, 105; "Un Référendum artistique et social," L'Ermitage, 7 (July 1893), 1-24.

"Henri Albert, "Les livres," La Revue indépendante, 22 (Jan.-March 1892), 131.

${ }^{86}$ Henri Albert, "Friedrich Nietzsche (1)," Mercure de France, 7 (Jan. 1893), 48. 65.

${ }^{87}$ Henri Albert, "Un manifeste littéraire Allemand," Mercure de France, 8 (May 1893),

Henri Albert, "Friedrich Nietzsche (suite)," Mercure de France, 7 (Feb. 1893), 172. 
Daniel Halévy, Eugène de Roberty, and Georges Palante, Albert conceived of Nietzsche as a socialist whose ideas would liberate the proletariat from its chains. ${ }^{89}$

As a further indication of Nietzsche's growing popularity in France, in 1894 the directors of the Mercure called for contributors to translate, under Henri Albert's guidance, the complete works of the philosopher. Noting the "pious cares" of Elisabeth Förster-Nietzsche, who "consecrated her entire life to the ideas of her brother" by planning his collected works in German, Albert promised in November that "France will soon also have her Nietzsche-in translation." ${ }^{90}$ Hugues Rebell, who had translated some passages of Zarathustra for $L$ 'Ermitage, protested this collective project. "A translation is a work of intuition which demands not only care and intelligence, but also a spiritual kinship with the author. ... But how rare are those who work to penetrate the spirit of a work rather than merely follow the letter!"91 "My meeting with this grand spirit," Rebell revealed, "marks an epoch of my existence," and in his own translations "I have given him my affection and promised to devote my spare time to a translation and to a study of his work which will be worthy of him."92 In short, Rebell felt that such a project was too important to be entrusted to "unknowns." Despite his ardor and sincerity, however, Rebell was apparently not called upon to translate Nietzsche's works for the Mercure, nor did he produce translations for any other journal during the 1890s. In addition, he seems to have abandoned the idea for a study of Nietzsche as well. At his death in 1905 his resentment was still apparent: "I do not believe, despite my admiration for the great writer, that the complete translation of his oeuvre has had a happy influence on French thought."93 Nonetheless, despite the desire for a collective project, Henri Albert translated all but two of Nietzsche's works for the Mercure, thus spreading the ideas of the philosopher to an even wider French audience. ${ }^{94}$

By 1895 even the conservative Revue de Paris had to admit the Nietzsche vogue among French youths. The philosopher appeals to a wide variety of

\footnotetext{
89 Several historians have expanded upon the paradoxical phenomenon of "Nietzschean socialism," such as Bianquis, 89-95; Thatcher, 93-98; R. Hinton Thomas, Nietzsche in German Politics and Society, 1890-1918 (La Salle, 111., 1983); Steven E. Aschheim, "Nietzschean Socialism-Left and Right, 1890-1933" Journal of Contemporary History, 23 (April 1988), 147-68; Rosenthal, Nietzsche in Russia; Seth Taylor, Left-Wing Nietzscheans: The Politics of German Expressionism, 1910-1920 (New York, 1990); and Christopher E. Forth, "Nietzsche, Sorel, and French Nietzschean Socialism," E.C. Barksdale Lectures, 1992 (12), forthcoming.

${ }^{90}$ André Billy notes that Albert had obtained the permission of Elisabeth Förster-Nietzsche to proceed with his translations. Cf. Billy, 112; Henri Albert, "Les Oeuvres complètes de Nietzsche," Mercure de France, 7 (Nov., 1894), 449, 450.

91 Hugues Rebell, "Sur une traduction collective des oeuvres de Nietzsche," Mercure de France, 13 (Jan. 1895), 100.

92 Ibid, 101.

${ }^{93}$ Rebell quoted in Le Cardonnel et Vellay, La Littérature contemporaine, 109.

94 Henri Albert's translations for the Mercure de France from 1898 to 1914 were: Ainsi parlait Zarathoustra (1898), Le Crépuscule des idoles, Le Cas Wagner, Nietzsche contre
} 
people, Andre Hallays noted, all of whom are "a youth disheartened with democracy."95 And, in a Mercure de France survey of intellectuals regarding the influence of German culture in French letters, notable writers such as Paul Adam, Maurice Barrès, Bernard Lazare, and Téodor de Wyzewa cited the influence of Nietzsche. When Jacques Morland resurrected the enquête in 1902, the number of writers attesting to Nietzsche's influence increased dramatically, as it did in subsequent literary surveys of 1905 and $1911 .{ }^{96} \mathrm{Clearly}$, enthusiasm for Nietzsche among French writers mounted from the early 1890 s through the First World War, suggesting that the philosopher was not only a source of energy for the "decadent" generation of 1890 , but a significant cultural fashion in French intellectual life whose ideas gained currency throughout the pre-war years. ${ }^{97}$

The writer Louis Reynaud remembered that "it is above all in the symbolist and decadent chapels that Nietzsche recruits his admirers."98 Such a recruitment may also be considered a conversion. The scholar Guy Michaud notes that the language of Nietzsche, "prophetic and sybillin, had been a revelation for the Symbolists" and had prompted many to enroll in a new school of thought: "School of energy and power, school of will, school of creative joy: this had been the effect of what became the work of Nietzsche in France." 99 By the turn of the century many former Symbolists had abandoned their Wagnerian faith for the philosophy of energy and power. ${ }^{100}$ Even Edouard Dujardin, the former

Wagner, L'Antéchrist, Pages choisis (1899), La Généalogie de la morale (1900), 'Aurore, Le Gai savoir (1901), Le Voyageur et son ombre (1902), Le Volontè de puissance, Par delà le bien et le mal (1903), Considérations inactuelles (1907), Ecce Homo (1909), and Le Cas Wagner (1914). These do not include the numerous excerpts which appeared in the Mercure and several other journals, including L'Ermitage and La Société nouvelle. The two other Nietzsche translators for the Mercure were L. Weiscopf (Par delà de le bien et le mal [1898]) and the socialist deputy Alexandre M. Desrousseaux (Humain, trop humain [1899]).

${ }^{95}$ André Hallays, "De l'influence des littératures étrangères," Revue de Paris, 2 (15 Feb. 1895), 883.

${ }^{9}$ One of the standard questions of the 1905 survey regarded the influence of Nietzsche in French letters. The 1911 survey, which dealt only with the question of Nietzsche's influence, was acknowledged (and dismissed) by Agathon (p. 55). In addition, between 1912 and 1914 several other enquétes were conducted by various periodicals to test Agathon's conclusions-interestingly, a 1914 survey revealed the marked influence of the ideas of Nietzsche and Ibsen among young women. Cf. Alfred Vallette, "Une Enquête Franco-Allemande," Mercure de France, 14 (April 1895), 3, 8, 16, 30; Jacques Morland, "Enquête sur l'influence allemande," Mercure de France, 44 (Nov. 1902), 289-647, 647-95; Le Cardonnel et Vellay, La Littérature contemporaine (1905), 60, 65, 80, 82, 85-86, 109, 248; Jean Viollis, "Nietzsche et la Jeunesse d'aujourd'hui," La Grande revue, 65 (10 Jan. 1911), 319-31; Amélie Gayraud, Les jeunes filles d'aujourd'hui (Paris, 1914), 33, 271.

${ }^{97}$ For information on the Nietzsche vogue among French elites, $\mathrm{Cf}$. Emilien Carassus, Le Snobisme et les lettres françaises (Paris, 1966), 358-64; Paris-Parisien 1902 (Paris, 1902), 31.

${ }^{98}$ Louis Reynaud, L 'Influence allemande en France au XVIIIe et au XIXe siècle (Paris, 1922), 281.

${ }^{99}$ Guy Michaud, Message poétique du symbolisme tome III (Paris, 1947), 522.

${ }^{100}$ As Jean Pierrot notes, the final collapse of Symbolism was hastened in the last two years of the century, largely due to the Dreyfus Affair, but also the deaths, illnesses, or religious 
editor of La Revue wagnérienne, rejected his youthful penchant for the ideas of the composer. "Wagner is à la mode," he wrote in 1903, "which means that he is neither liked nor understood anymore." Fifteen years earlier, Dujardin conceded, Wagner played a significant role in French letters. "But times change. The German spirit, by an admirable phenomenon, has just repudiated itself by producing the great man who, while German, represents the pure classical French tradition; I mean to speak of Nietzsche." ${ }^{101}$ In fact, as tensions with Germany increased after 1905 the thought of Wagner, who hated the French, fell out of favor among many intellectuals. ${ }^{102}$ As the Symbolist worldview gave way to an overt call for nationalism and energy, the ideas of the - francophile Nietzsche were appropriated by many French writers as a cultural weapon against Germany. For others such as Agathon specifically French exemplars like Stendhal and Henri Bergson would serve this purpose. Years earlier, however, the initial and perhaps necessary step in Nietzsche's reception in France was his use as a weapon against decadent Symbolism-an assault which coincided with the call of many French intellectuals for cultural and political regeneration.

State University of New York at Buffalo.

conversions of certain key Symbolist writers, such as Mallarmé, Georges Rodenbach, Gustave Moreau, Camille Mauclair, Rémy de Gourmont, and Marcel Schwob. Cf. Pierrot, 241-42.

${ }^{101}$ Edouard Dujardin, contribution to Jacques Morland, "Enquête sur l'influence allemande," Mercure de France, 45 (Jan. 1903), 94-95.

102 Digeon, 454-55; Camille Mauclair, "La fin du wagnérisme," La Revue des revues, 48 (15 Feb. 1904), 464-73; Paris-Parisien 1902, 26. 